\title{
Chronic Wasting Disease: Status, Science, and Management Support by the U.S. Geological Survey
}

By Christina M. Carlson, M. Camille Hopkins, Natalie T. Nguyen, Bryan J. Richards, Daniel P. Walsh, and W. David Walter

\section{Background and Significance}

Chronic wasting disease (CWD) is an emerging infectious disease that is fatal to free-ranging and captive animals in Cervidae (the deer family; referred to as "cervids"). Affected animals include some Odocoileus, Cervus, and Muntiacus species (deer), Cervus canadensis (elk), Alces alces (moose), and Rangifer taran$d u s$ (reindeer). Once an animal is infected, CWD typically causes neurological damage that grows more severe until the host animal dies. Originally identified in 1967, to date (early 2018), the disease has been found in 24 States as well as Canada, South Korea, and Norway. It continues to spread across North America through new and ongoing outbreaks (fig. 1). In addition, the proportion of CWD-infected animals is increasing in many areas where the disease is already established. For example, the proportion of adult male and female Odocoileus virginianus (white-tailed deer) in north-central Iowa County, Wisconsin, that tested positive for CWD has more than doubled during a 6-year period (2011-16). Approximately 40-50 percent of the adult male population and 20-30 percent of the adult female population was infected by 2016, making north-central Iowa County one of the most heavily affected regions in the United States (Wisconsin Department of Natural Resources, 2017). In some heavily affected areas, total cervid numbers have decreased over time due to CWD, which suggests that these cervid populations may not be sustainable in the long-term (Miller and others, 2008; Almberg and others, 2011; Monello and others, 2014; Geremia and others, 2015; Edmunds and others, 2016; DeVivo and others, 2017). In east-central Wyoming, the number of wild white-tailed deer in a study population declined 10.4 percent annually between 2003 and 2010. Moreover, deer that tested positive for the causative CWD agent were 4.5 times more likely to die each year than deer that tested negative (Edmunds and others, 2016). In sympatric mule deer, the population declined by 21 percent annually during a 5 -year study, and researchers concluded that CWD was a significant causative factor in this decline (DeVivo and others, 2017). In addition to CWD's effects on free-ranging cervids, the disease also directly impacts captive herds. CWD has been identified in over 175 North American captive cervid facilities (fig. 1) where infection rates have approached 80 percent (Keane and others, 2008) and have resulted in the destruction of all individual deer within most of these facilities and costly government compensation associated with this animal depopulation. Current evidence strongly suggests CWD has been transmitted between captive and free-ranging cervids and that the movement of cervids, through both natural and human-assisted means, is one of the greatest risk factors in spreading CWD to new areas (Bollinger and others, 2004; Haley and Hoover, 2014).

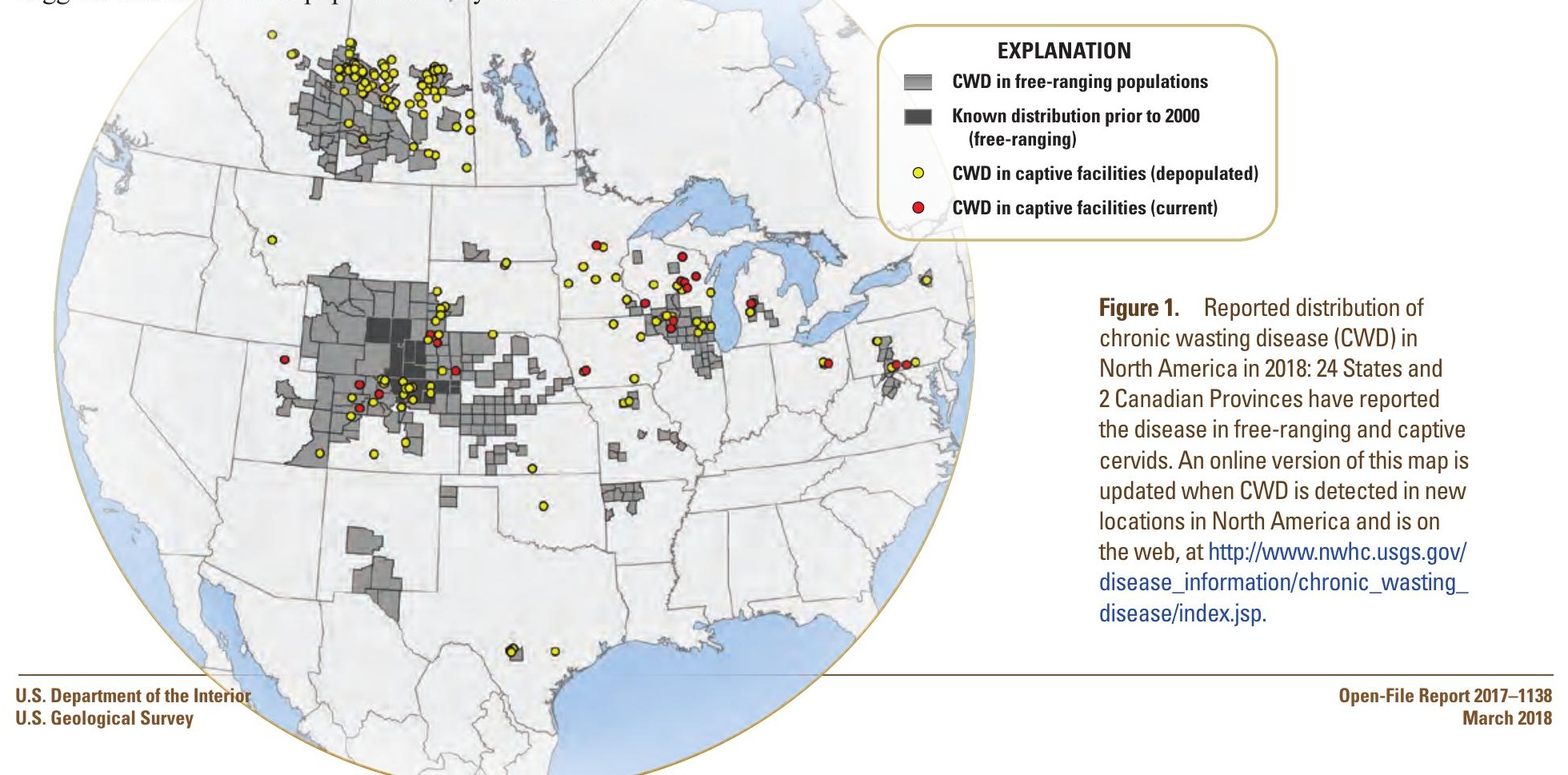


In addition to direct disease impacts on cervids, CWD may also impart economic, social, and ecological effects, and complicate cervid management. For example, the State of Wisconsin spent \$32.3 million on CWD surveillance and management from 2001 to 2006 to address the disease and monitor its spread (Wisconsin Legislative Audit Bureau, 2006). In the United States, big game hunting is enjoyed by 11.6 million hunters, and it provides 212 million person-days (the amount of recreation time in days contributed by all participating persons) of hunting recreation and contributes approximately $\$ 170$ billion to the nation's economy each year (2011 figures; U.S. Fish and Wildlife Service and U.S. Census Bureau, 2014). Surveys of deer hunters suggest nearly half would stop hunting if approximately 50 percent of wild deer became infected with the CWD agent or if a human-health risk from CWD was identified (Needham and others, 2004; Vaske and Lyon, 2011). Decline in hunter participation results in loss of hunting-related revenue (including travel, equipment, and license sales) that supports the economic stability of many local communities and directly funds wildlife management and conservation efforts (Needham and others, 2004). In addition to local communities, the movement of CWD presents a threat to tribal culture and a traditional tribal food source (Great Lakes Indian Fish and Wildlife Commission, 2018). Hunting is a primary tool for managing and controlling cervid populations; overabundant cervid populations facilitate spread of some cervid diseases and lead to ecologic and economic damage (Côté and others, 2004). For example, overbrowsing and foraging by deer can inflict major economic losses on forestry and agriculture and negatively impact the abundance and diversity of forest vegetation and wildlife (Côté and others, 2004).

\section{What is Chronic Wasting Disease?}

CWD is one member of a family of diseases called transmissible spongiform encephalopathies (TSEs), which includes scrapie in sheep and goats, bovine spongiform encephalopathy (commonly called "mad cow disease") in cattle, and CreutzfeldtJakob disease in humans. CWD is the only TSE known to affect free-ranging wildlife. The causative agents of TSEs are thought to be prions (pronounced PREE-ons) (Prusiner, 1982). Prions are unconventional pathogenic agents that are comprised mostly, if not entirely, of a misfolded, infectious form of a normally occurring host protein. Prion proteins are found most abundantly in mammalian brain and central nervous system tissues. Prions are unique when compared to all other known pathogens, in part because they do not have a nucleic acid genome, such as DNA. Other known pathogens, such as viruses and bacteria, need DNA or RNA to replicate, while prions do not. Additionally, prions exhibit an extraordinary resistance to common treatments used to stop other infectious agents, such as ultraviolet and ionizing radiation, exposure to chemical disinfectants, and heat treatments (Colby and Prusiner, 2011). Prions typically infect hosts in a species-specific manner, and CWD prions can be passed via direct transmission between susceptible cervids and by indirect transmission through contact with contaminated materials in the environment (Miller and others, 2004). Following a protracted incubation period during which there are no outward signs of disease, CWD-positive animals suffer progressive neurological degeneration that causes physiological and behavioral changes (listlessness, excessive drinking and urination, lowering of head, weight loss) and, ultimately, death (Williams and Young, 1980).

Light microscopy images of $A$, healthy deer lymphoid tissue. $B$, CWD-infected deer lymphoid tissue. CWD prion protein deposition in lymphoid follicles is indicated by red staining. Staining for disease-associated prion protein in brain or Iymphoid tissues is the primary method used for diagnostic testing to confirm a CWD diagnosis. (Photo from USGS National Wildlife Health Center files.) ISE
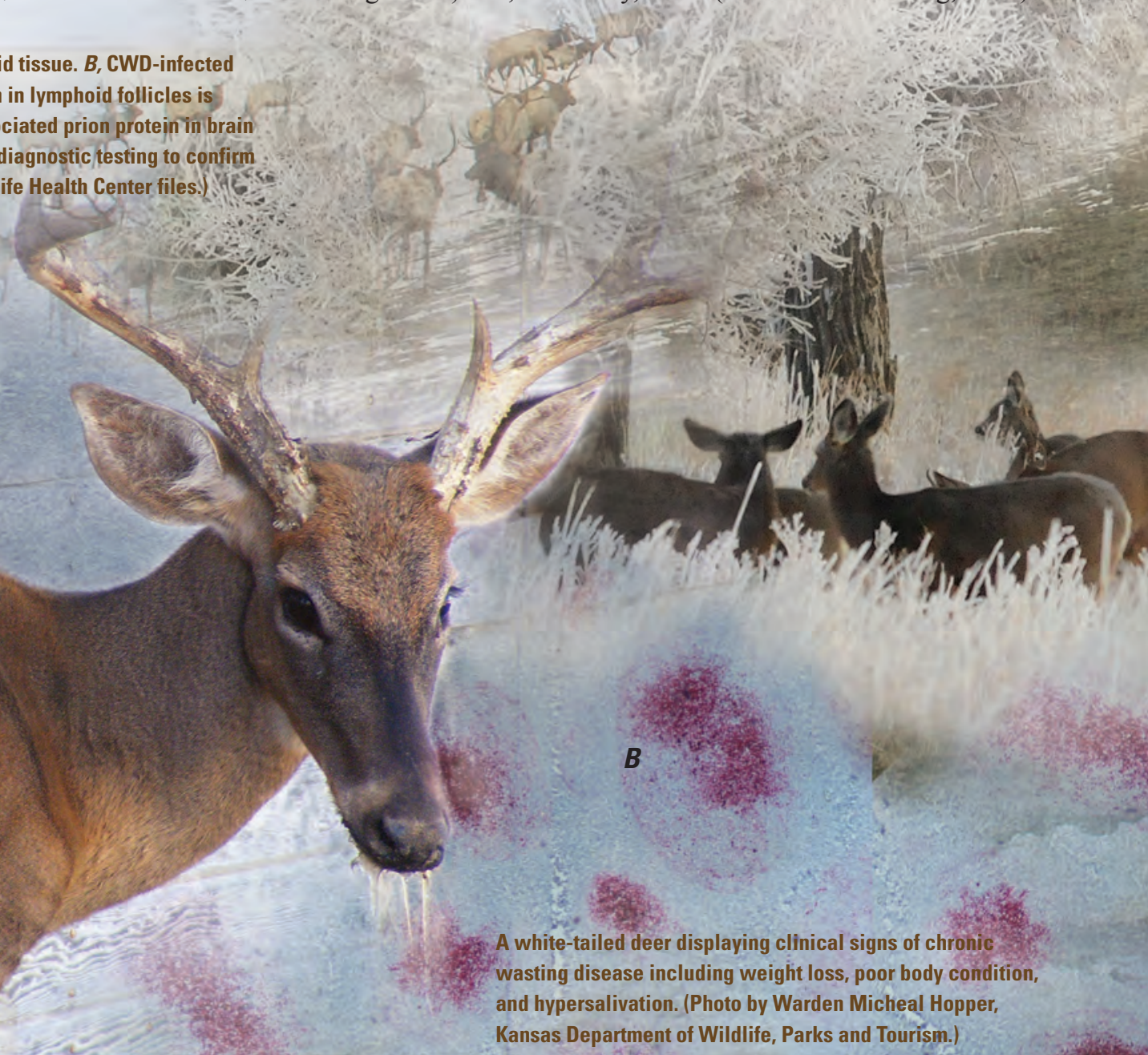


\section{Current Status of Chronic Wasting Disease}

The disease is currently spreading geographically and has recently been detected in additional cervid species. CWD was first detected outside North America when infected Canadian elk were exported to South Korea between 1994 and 1997, and the disease spread between captive cervids (Sohn and others, 2002; Kim and others, 2005,). In 2016, the disease was detected for the first time in free-ranging reindeer, moose, and Cervus elaphus atlanticus (red deer) in Norway (Benestad, 2016; Norwegian Veterinary Institute, 2017).

The extraordinary stability of the CWD prion allows it to remain infectious in the environment for years, posing longterm potential risks to agricultural, wildlife, and public health (Miller and others, 2004). Noncervid species may be directly or indirectly exposed to CWD prions on the landscape through urinary, salivary, or fecal shedding from infected animals or decomposition of diseased carcasses. Although the risks of CWD transmission between species are not completely characterized, infection of noncervid species with CWD prions has not been reported under natural conditions. However, rodents (voles, mice, and hamsters), carnivores (ferrets, mink, and cats), livestock (cattle, sheep, goats, and pigs), and primates (squirrel monkeys and cynomologus macaques) have been experimentally infected. Some of these experiments use natural routes of exposure, such as feeding of prion-infected meat (Haley and Hoover, 2014; Moore and others, 2017; Czub and others, 2017). Although there are no current reported cases of natural CWD prion infection in humans, the successful experimental infection of two species of nonhuman primates raises concern over the potential for CWD to be transmitted to humans. Consistent with this concern, the Centers for Disease Control and Prevention (2015), the World Health Organization (2012), and many local public health departments advise against human consumption of CWD-infected animal parts or products.

Although the long-term effects of CWD on wildlife and ecosystems remain unclear, its documented and potential impacts make it a primary concern for natural resource management agencies in the United States and Canada. Effective vaccines and treatments do not currently exist and efforts to control or eradicate the disease from free-ranging cervid populations have been largely ineffective (Haley and others, 2014). Therefore, current management strategies include implementing strong preventative measures to reduce or disrupt CWD spread in cervids (Williams and others, 2002;DeVivo and others, 2017). Additional scientific studies could help provide a better understanding of the risks and disease dynamics of CWD, forecast short- and long-term impacts of the disease, and develop effective strategies for prevention and control.

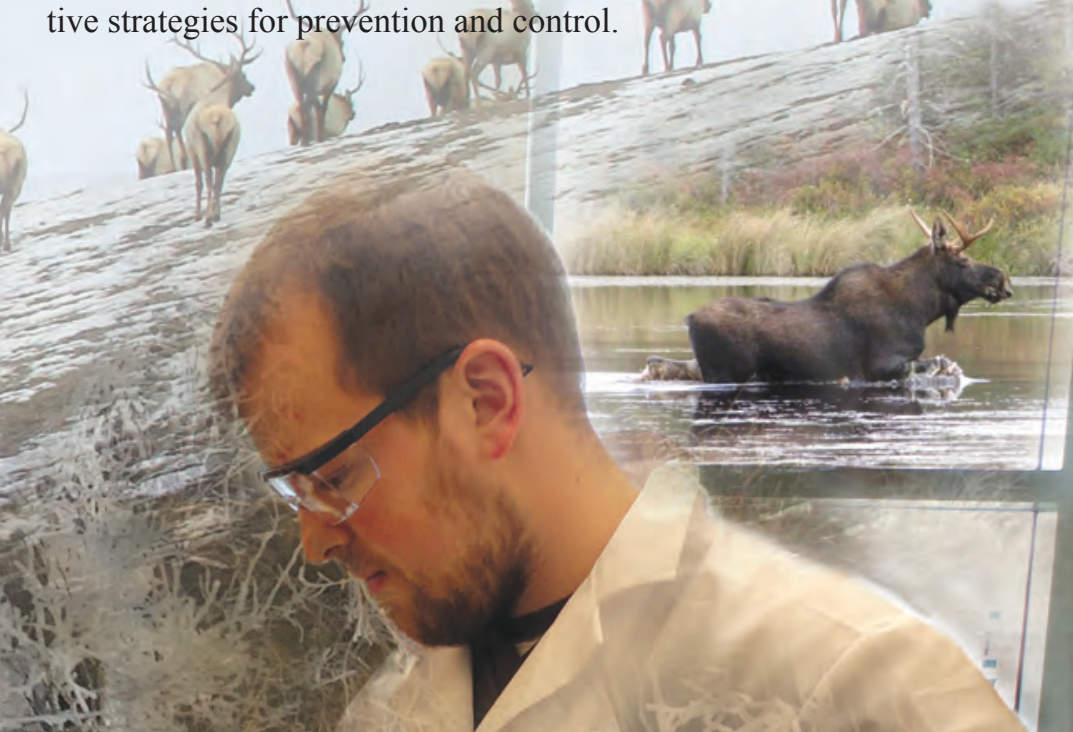




\section{U.S. Geological Survey Science to Support Management of Chronic Wasting Disease}

The U.S. Geological Survey (USGS) investigates CWD at multiple science centers and cooperative research units across the Nation (fig. 2) and supports the management of CWD through science-based strategies. CWD research conducted by USGS scientists has three strategies: (1) to understand the biology, ecology, and causes and distribution of CWD; (2) to assess and predict the spread and persistence of CWD in wildlife and the environment; and (3) to develop tools for early detection, diagnosis, surveillance, and control of CWD (table 1).

Figure 2. The U.S. Geological Survey science centers and cooperative research units conducting chronic wasting disease research and technical assistance for the United States.

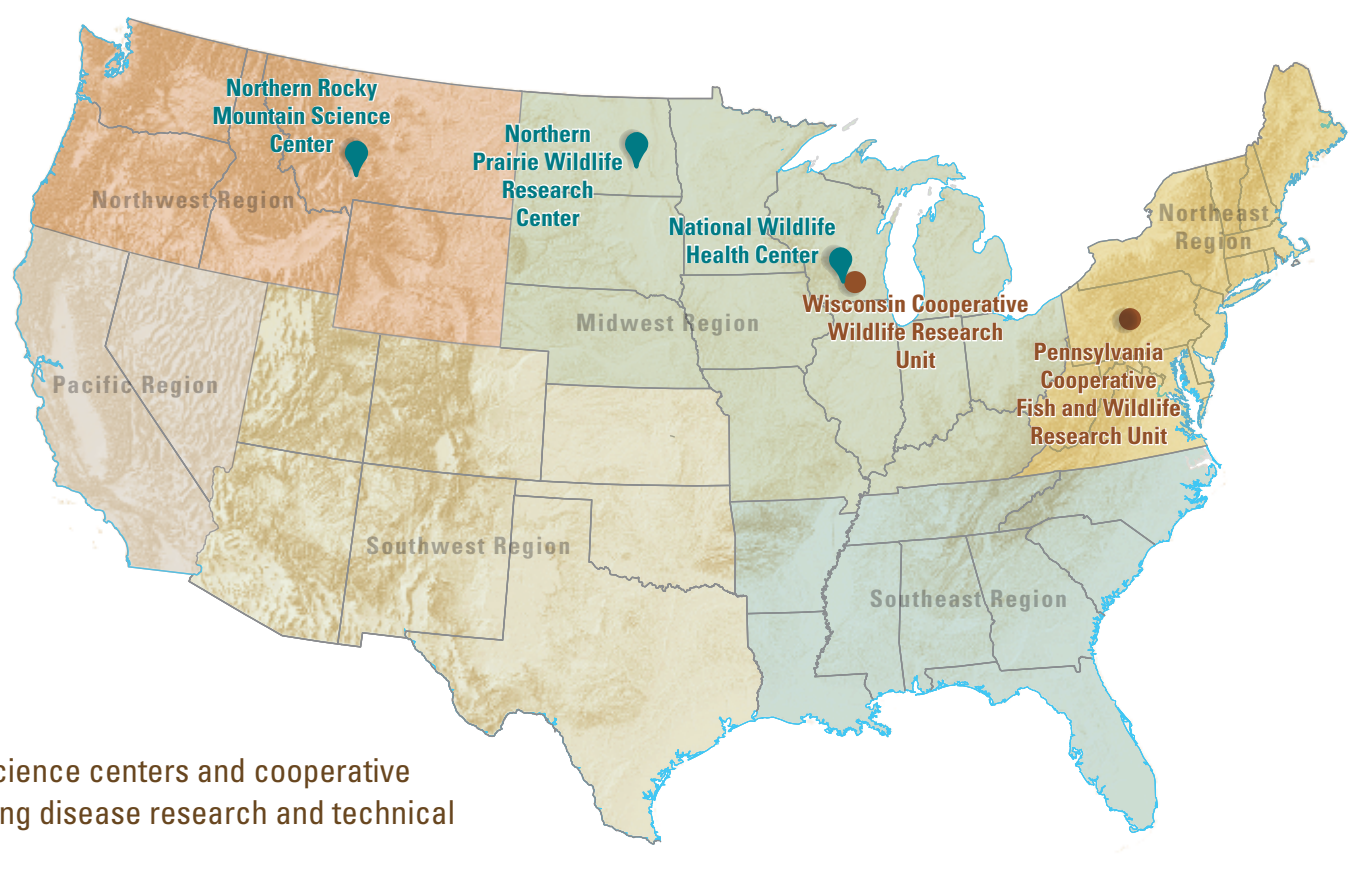

Table 1. U.S. Geological Survey Contributions to Understanding Chronic Wasting Disease.

[USGS, U.S. Geological Survey; CWD, chronic wasting disease]

\section{USGS scientists work to:}

Biology, ecology and epidemiology of CWD

The USGS Northern

Prairie Wildlife Research Center and the National Park Service are evaluating effects of elk density on survival and chronic wasting disease prevalence at Wind Cave National Park, South Dakota (Photo, immediately right, courtesy of the National Park Service, Wind Cave National Park).
- analyze the individual genetic characteristics that influence cervid risk of being infected with CWD.

- study how CWD prions change over time.

- study CWD transmission, spread, and prevention in free-ranging and captive cervids.

- assess the effect of CWD on cervid survival and long-term population growth.

- identify and investigate the species that harbor CWD and the ecological factors that may facilitate CWD transmission, including the potential roles of soil, plants, and wild rodents.

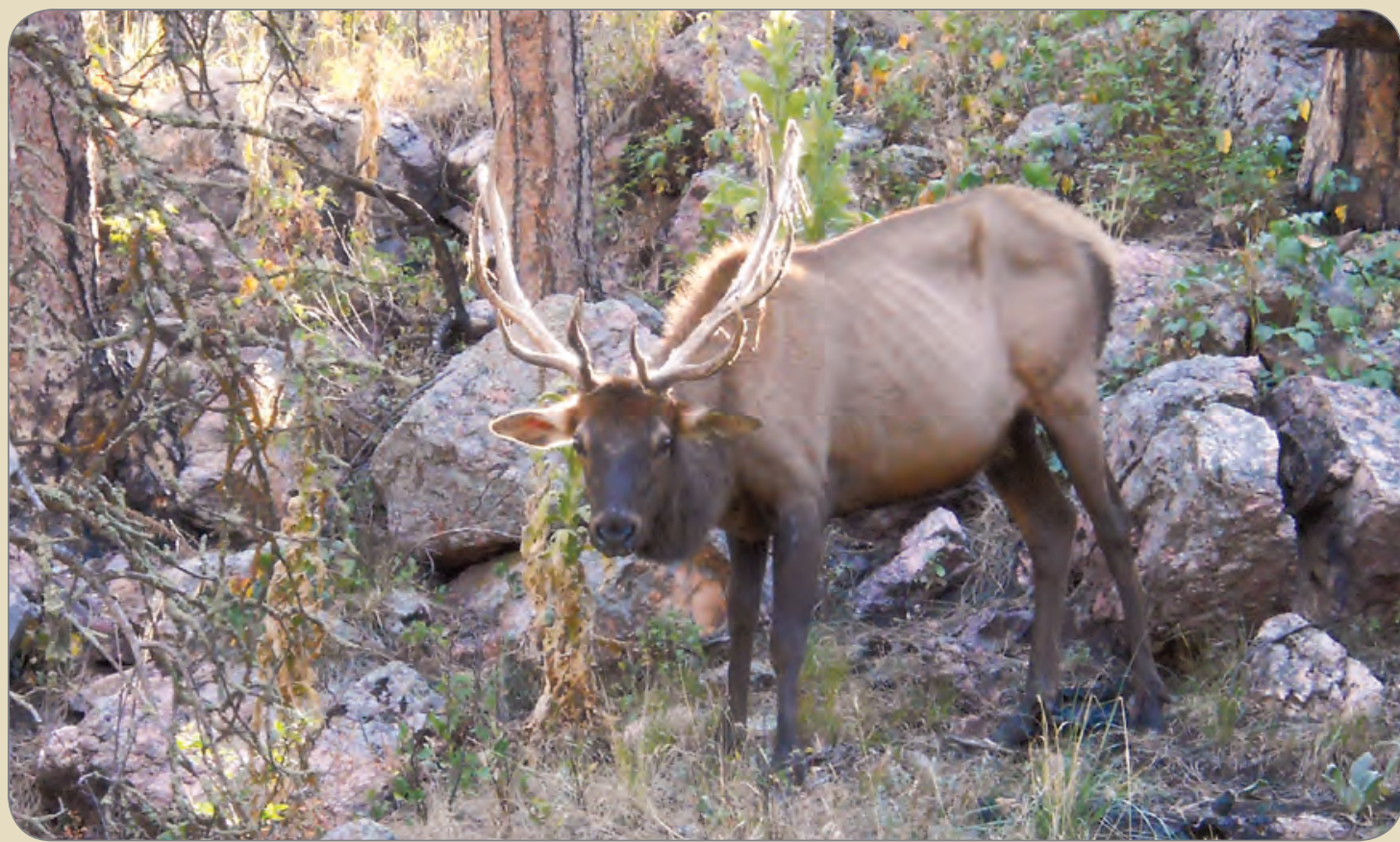




\section{USGS scientists have the capabilities to:}

CWD risk

assessment and modeling

Figure, right, shows the measured and forecasted growth and spread of CWD in white-tailed deer in the core area where CWD occurs in Wisconsin, USA. (Reference and image credit: Hefley and others 2017)
- identify risk factors for CWD prion infection and areas at high risk for CWD introduction.

- predict the risk of disease transmission among and between captive and free-ranging cervids.

- assess how different management approaches affect disease transmission, spread, persistence, and control.

- investigate the potential for CWD transmission from cervids to other wildlife, domestic species, and humans.

- develop tools or techniques for predicting CWD growth within free-ranging cervid populations and forecasting disease spread in regions of interest.

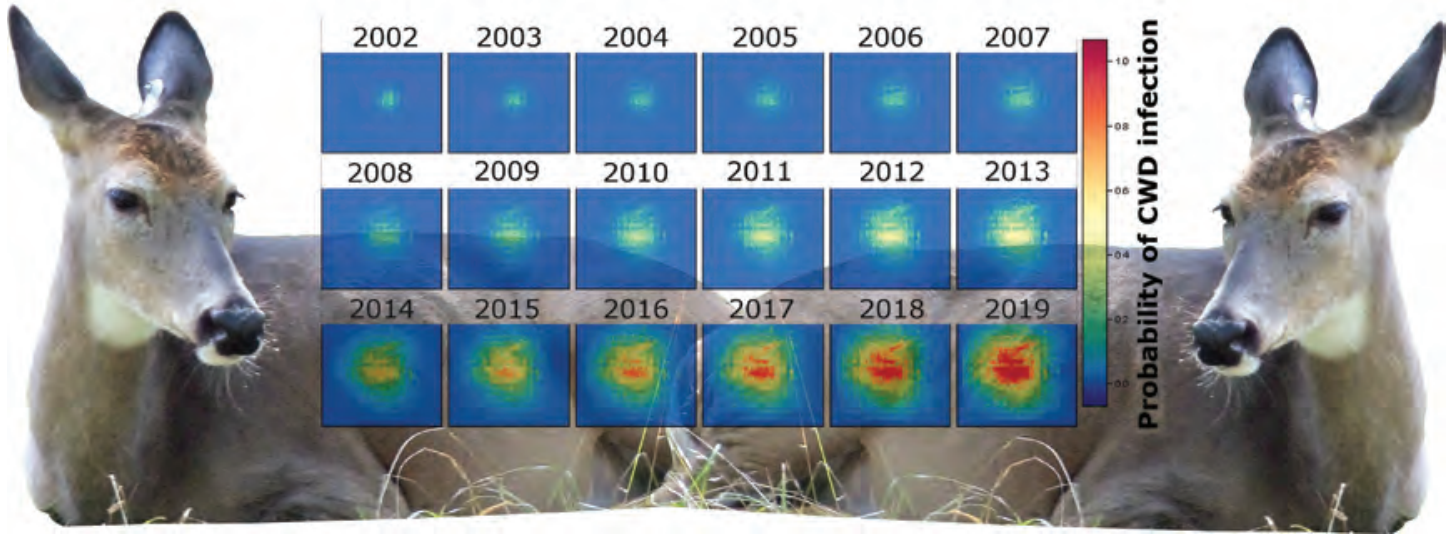

\section{USGS scientists are investigating new and improved methods to:}

CWD surveillance and mitigation

The USGS National Wildlife Health Center assisted Montana Fish, Wildlife \& Parks to develop risk maps for CWD which helps inform the State's surveillance program. To the right is a map including information from recent (2015) detections of CWD. (Reference and image credit: Russell and others, 2015)
- increase the efficiency of CWD surveillance programs.

- detect CWD prions in living and deceased animals and the environment.

- decontaminate natural and agricultural areas and disrupt disease transmission.

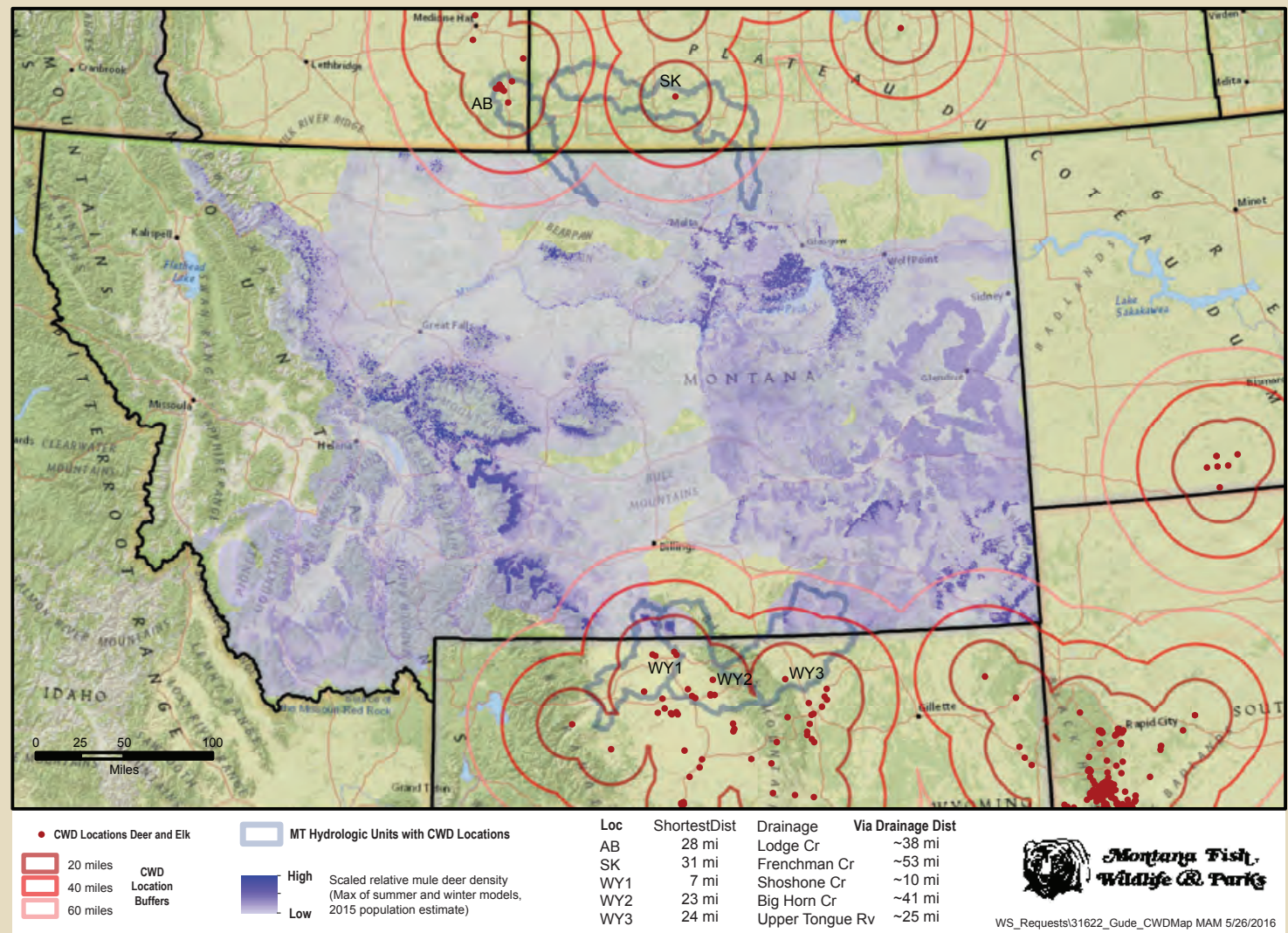


Through a comprehensive, multidisciplinary research program, the USGS is providing cutting-edge science to help inform management of this challenging disease. USGS research has been instrumental in developing surveillance strategies for early detection of CWD in Montana and Shenandoah National Park in Virginia (Russell and others, 2015); identifying high risk areas for potential CWD transmission between wild and farmed deer in Pennsylvania (Carrollo, 2016); and identifying potential disease risks posed by CWD to noncervid species, such as bighorn sheep (Morawski and others, 2013). The benefits of USGS research on CWD extend beyond wildlife management. For example, USGS scientists identified a novel enzyme from lichens with the ability to breakdown infectious prion protein, which could be useful for decontaminating human hospital environments (Johnson and others, 2011). The USGS is committed to finding solutions to this challenging disease and providing research that has multiple benefits for wildlife health as well as environmental, agricultural, and, potentially, human health.

\section{U.S. Geological Survey Web Links and Selected Publications}

USGS Ecosystems CWD:

https://www2.usgs.gov/ecosystems/disease/cwd.html

USGS National Wildlife Health Center: http://www.nwhc.usgs.gov/

USGS Northern Rocky Mountain Science Center:

https://www.usgs.gov/centers/norock/

USGS Northern Prairie Wildlife Research Center: http://www.npwrc.usgs.gov/

Pennsylvania Cooperative Fish and Wildlife Research Unit: http://www.coopunits.org/Pennsylvania/

Wisconsin Cooperative Wildlife Research Unit: http://www.coopunits.org/Wisconsin_Wildlife/

USGS Publications Warehouse: https://pubs.er.usgs.gov/
Background photo. Scientists from the U.S. Geological Survey National Wildlife Health Center have identified an enzyme found in various species of lichens, including Parmelia sulcata, that are able to degrade infectious prion protein. Current research is focused on application of this lichen enzyme in decontamination of human hospital environments (Johnson and others 2011). (Photo by Christina Carlson, USGS, National Wildlife Health Center.)

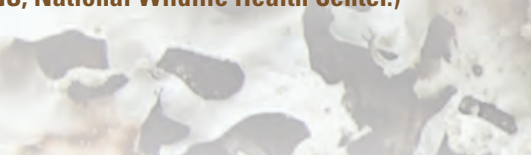

Photo below. Research from the U.S. Geological Survey National Wildlife Health Center indicates that bighorn sheep could be vulnerable to CWD from either white-tailed deer or elk and to a domestic sheep prion disease known as scrapie (Morawski and others 2013). (Photo by Jim Peaco, U.S. National Parks Service 2004.)

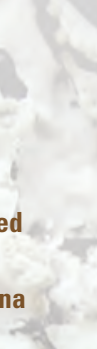
ot 


\section{References Cited}

Almberg, E.S., Cross, P.C., Johnson, C.J., Heisey, D.M. and Richards, B.J., 2011, Modeling routes of chronic wasting disease transmission: environmental prion persistence promotes deer population decline and extinction: PLoS One, v. 6, no. 5, p. e19896, accessed October 5, 2017, at https://doi.org/10.1371/journal.pone.0019896.

Benestad, S.L., Mitchell, Gordan, Simmons, Marion, Ytrehus, Bjørnar, and Vikøren, Turid, 2016, First case of chronic wasting disease in a Norwegian free-ranging reindeer: Veterinary Research, v. 47, no. 88, accessed October 5, 2017, at https://doi.org/10.1186/s13567-016-0375-4.

Bollinger, Trent, Caley, Peter, Merrill, Evelyn, Messier, Francois, Miller, M.W., Samuel, M.D., and Vanopdenbosch, Emmanuel, 2004, Chronic wasting disease in Canadian wildlife: an expert opinion on the epidemiology and risks to wild deer: Canadian Cooperative Wildlife Health Centre, University of Saskatchewan, p. 1-32.

Carrollo, E.M., 2016, Exploration of methods for analysis of resource selection using location-based data: University Park, Pennsylvania State University, Master's Thesis, p. 1-71.

Centers for Disease Control and Prevention, 2015, Chronic wasting disease prevention: Centers for Disease Control CWD web page, accessed October 5, 2017, at http://www.cdc.gov/ prions/cwd/prevention.html.

Colby, D.W., and Prusiner, S.B., 2011, Prions: Cold Spring Harbor Perspectives in Biology, v. 3, p. a006833, accessed October 5, 2017, at http://cshperspectives.cshlp.org/content/3/1/a006833.full.

Côté, S.D., Rooney, T.P., Tremblay, J.P., Dussault, C., and Waller, D.M., 2004, Ecological impacts of deer overabundance: Annual Review of Ecology, Evolution, and Systematics, v. 35, p. 113-147.

Czub, Stefanie, Schulz-Schaeffer, Walter, Stahl-Henning, Christine, Beekes, Michael, Schaetzl, Hermann, and Motzkus, Dirk, 2017, First evidence of intercranial and peroral chronic wasting disease (CWD) into cynomologous macaques: a work in progress: in PRION2017 Conference: Deciphering Neurodegenerative Diseases, accessed October 5, 2017, at http://prion2017.org/programme/.

DeVivo, M.T., Edmunds, D.R., Kauffman, M.J., Schumaker, B.A., Binfet, J., Kreeger, T.J., Richards, B.J., Schatzl, H.M., and Cornish, T.E., 2017, Endemic chronic wasting disease causes mule deer population decline in Wyoming: PLoS ONE, v. 12 , no. 10, p. e0186512, accessed January 29, 2018, at http://journals.plos.org/plosone/article?id=10.1371/journal. pone. 0186512 .

Edmunds, D.R., Kaufmann, M.J., Schumaker, B.A., Lindzey, F.G., Cook, W.E., Kreeger, T.J., Grogran, R.G., and Cornish, T.E., 2016, Chronic wasting disease drives population decline of white-tailed deer: PLoS ONE, v. 11, no. 8, p. e0161127, accessed October 5, 2017, at https://doi.org/10.1371/journal. pone. 0161127.
Geremia, Chris, Miller, M.W., Hoeting, J.A., Antolin, M.F., and Hobbs, N.T., 2015, Bayesian modeling of prion disease dynamics in mule deer using population monitoring and capture-recapture data: PLoS One, v. 10, no. 10, p. e0140687, accessed October 5, 2017, at https://doi.org/10.1371/journal. pone. 0140687.

Great Lakes Indian Fish and Wildlife Commission, 2018, Chronic Wasting Disease (CWD) web page, accessed January 29, 2018, at https://data.glifwc.org/cwd/.

Haley, N.J., and Hoover, E.A., 2014, Chronic wasting disease of cervids: current knowledge and future perspectives: Annual Review of Animal Biosciences, v. 3, p. 305-325.

Hefley, T.J., Hooten, M.B., Russell, R.E., Walsh, D.P., and Powell, J.A., 2017, When mechanism matters: Bayesian forecasting using models of ecological diffusion: Ecology Letters, v. 20, no.5, p. 640-650, accessed October 5, 2017, at http://onlinelibrary.wiley.com/doi/10.1111/ele.12763/full.

Johnson, C.J., Bennett, J.P., Biro, S.M., Duque-Velasquez, J.C., Rodriguez, C.M., Bessen, R.A., and Rocke, T.E., 2011, Degradation of the disease-associated prion protein by a serine protease from lichens: PLoS ONE, v. 6, no. 5, p. e19836, accessed October 5, 2017, at https://doi.org/10.1371/journal. pone. 0019836 .

Keane, D.P., Barr, D.J., Bochsler, P.N., Hall, S.M., Gidlewski, Thomas, O'Rourke, K.I., Spraker, T.R., and Samuel, M.D., 2008, Chronic wasting disease in a Wisconsin white-tailed deer farm: Journal of Veterinary Diagnostic Investigation, v. 20 , no. 5 , p. 698-703.

Kim, T.Y., Shon, H.J., Joo, Y.S., Mun, U.K., Kang, K.S., and Lee, Y.S., 2005, Additional cases of chronic wasting disease in imported deer in Korea: The Journal of Veterinary Medical Science, v. 67, no. 8, p. 753-759.

Miller, M.W., Williams, E.S., Hobbs, N.T., and Wolfe, L.L., 2004, Environmental sources of prion transmission in mule deer: Emerging Infectious Diseases, v. 10, no. 6, p. 1003-1006.

Miller, M.W., Swanson, H.M., Wolfe, L.L., Quartarone, F.G., Huwer, S.L., Southwick, C.H., and Lukacs, P.M., 2008, Lions and prions and deer demise: PLoS One, v. 3, no. 12, p. e4019, accessed October 5, 2017, at https://doi.org/10.1371/journal. pone. 0004019 .

Monello, R.J., Powers, J.G., Spraker, T.R., Watry, M.K., and Wild, M.A., 2014, Survival and population growth of freeranging elk population with a long history of exposure to chronic wasting disease: The Journal of Wildlife Management, v. 78 , no. 2 , p. 214-223.

Moore, S.J., Greenlee, M.H.W., Kondru, N., Manne, S., Smith, J.D., Kunkle, R.A., Kanthasamy, A., and Greenlee, J.J., 2017, Experimental transmission of the chronic wasting disease agent to swine after oral or intracranial inoculation: Journal of Virology, , v. 91, no. 19, p. e00926-17, accessed October 5, 2017, at http://jvi.asm.org/content/ early/2017/07/06/JVI.00926-17.full.pdf+html. 
Morawski, A.R., Carlson, C.M., Chang, Haeyoon, and Johnson, C.J., 2013, In vitro prion protein conversion suggests risk of bighorn sheep (Ovis canadensis) to transmissible spongiform encephalopathies: BMC Veterinary Research, v. 9, no. 157, accessed October 5, 2017, at https://doi.org/10.1186/17466148-9-157.

Needham, M.D., Vaske, J.J., and Manfredo, M.J., 2004, Hunter's behavior and acceptance of management actions related to chronic wasting disease in eight states: Human Dimensions of Wildlife, v. 9, no. 3, p. 211-231.

Norwegian Veterinary Institute, 2017, Surveillance and eradication effort towards CWD web page, accessed January 29, 2018, at https://wwweng.vetinst.no/news/surveillance-and-eradicationeffort-towards-cwd-copy.

Prusiner, S., 1982, Novel proteinaceous infectious particles cause scrapie: Science, v. 216, no. 4542, p. 136-144.

Russell, R.E., Gude, J.A., Anderson, N.J., and Ramsey, J.M., 2015, Identifying priority chronic wasting disease surveillance areas for mule deer in Montana: Journal of Wildlife Management, v. 79, no. 6, p. 989-997.

Sohn, H.J., Kim, J.H., Choi, K.S., Nah, J.J., Joo, Y.S., Jean, Y.H., Ahn, S.W., Kim, O.K., and Balachandran, Aru, 2002, A case of chronic wasting disease in an elk imported to Korea from Canada: Journal of Veterinary Medical Science v. 64, no. 9, p. $855-858$.

Spraker, T.R., Miller, M.W., Williams, E.S., Getzy, D.M., Adrian, W.J., Schoonveld, G.G., Spowart, R.A., O’Rourke, K.I., Miller, J.M., and Merz, P.A., 1997, Spongiform encephalopathy in free-ranging mule deer (Odocoileus hemionus), white-tailed deer (Odocoileus virginanus) and Rocky Mountain elk (Cervus elaphus nelsoni) in northcentral Colorado: Journal of Wildlife Diseases, v. 33, no. 1, p. 1-6.
U.S. Department of the Interior, U.S. Fish and Wildlife Service, and U.S. Department of Commerce, U.S. Census Bureau, 2011, 2011 National Survey of Fishing, Hunting, and Wildlife-Associated Recreation: accessed October 5, 2017, at http://www.census.gov/prod/2012pubs/fhw11-nat.pdf.

USGS National Wildlife Health Center, 2017, Map of chronic wasting disease in North America: National Wildlife Health Center Chronic Wasting Disease web page, accessed October 5, 2017, at http://www.nwhc.usgs.gov/disease_information/chronic_wasting_disease/index.jsp.

Vaske, J.J., and Lyon, K.M., 2011, CWD prevalence, perceived human health risks, and state influences on deer hunting participation: Risk Analysis, v. 31, no. 3, p. 488-496.

Williams, E.S., Miller, M.W., Kreeger, T.J., Kahn, R.H., and Thorne, E.T., 2002, Chronic wasting disease of deer and elk: a review with recommendations for management: Journal of Wildlife Management, v. 66, p. 551-563.

Williams, E.S., and Young, S., 1980, Chronic wasting disease of captive mule deer: a spongiform encephalopathy: Journal of Wildlife Diseases, v. 16, no. 1, p. 89-98.

Wisconsin Department of Natural Resources, 2017, CWD prevalence trends: Wisconsin Department of Natural Resources Wildlife Habitat web page, accessed October 5, 2017, at http://dnr.wi.gov/topic/wildlifehabitat/prevalence.html.

Wisconsin Legislative Audit Bureau, 2006, An evaluation: Chronic wasting disease, Department of Natural Resources: Wisconsin Legislative Audit Bureau Report, accessed October 5, 2017, at http://legis.wisconsin.gov/lab/reports/06-13full.pdf.

World Health Organization, 2012, Variant Creutzfeldt-Jakob disease: World Health Organization Variant Creutzfeldt-Jakob disease web page, accessed October 5, 2017, at http://www. who.int/zoonoses/diseases/variantcjd/en/.

\section{For additional information contact:}

Ecosystems Mission Area

12201 Sunrise Valley Drive

Reston, VA 20192

\section{Director, USGS National Wildlife Health Center} 6006 Schroeder Road

Madison, WI 53711-6223

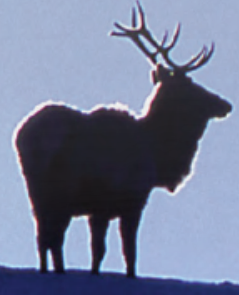

Publishing support provided by the

U.S. Geological Survey,

Science Publishing Network,

Madison Publishing Service Center
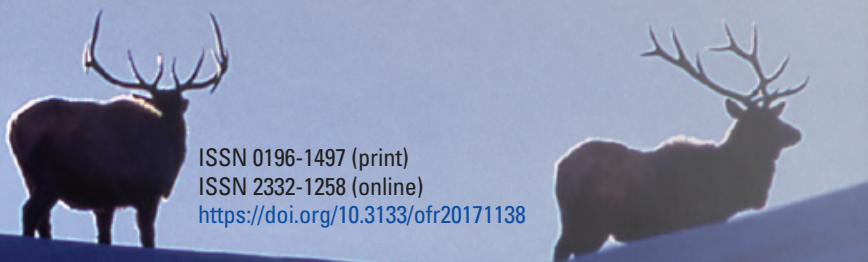